\title{
Effects Of Metacognition And Direct Instruction On Spelling Abilities Of Pupils With Learning Disabilities In Primary Schools In Ibadan, Oyo State, Nigeria
}

\author{
Lazarus, Kelechi Uchemadu, PhD \\ Ogunsola, Gabriel Ogundiya
}

Dept. of Special Education, University of Ibadan, Nigeria

\section{doi: 10.19044/esj.2016.v12n1p227 URL:http://dx.doi.org/10.19044/esj.2016.v12n1p227}

\begin{abstract}
This study investigated the effects of metacognition and direct instruction on spelling abilities of pupils with learning disabilities in Ibadan, Oyo State, Nigeria. Pre-test, post -test, control group, quasi-experimental design with 3x2x2 factorial matrix was adopted. Purposive sampling technique was used to select three public primary schools in Ibadan. Sixty primary three pupils with spelling disabilities were randomly selected from the sampled schools and randomized into metacognition, direct instruction and control group. Four instruments were utilized: Pupil Rating Scale ( $\mathrm{r}=$ 0.76), Right Word Recognition ( $\mathrm{r}=0$.91), Pupils’ English Note Book and Test of Verbal Ability ( $\mathrm{r}=0.96)$. Those who met the inclusion criteria were treated, while those in the control group received lessons in spelling instruction using the conventional method. Six hypotheses were tested at 0.05 level of significance. Data were analyzed using Analysis of Covariance. Despite the fact that there was no significant main effect of the treatment, participants who were exposed to direct instruction had the highest mean score of $(\bar{x}=46.35)$, this was followed by metacognition $(\bar{x}=44.90)$ while the control group obtained $(\bar{x}=30.93)$. There was no significant gender difference as male and female participants benefited equally from the treatment packages. Based on these findings, recommendations were made which included that teachers of pupils with learning disabilities should adopt the two strategies in teaching spelling to pupils with learning disabilities because these strategies proved better than the conventional method.
\end{abstract}

Keywords: Metacognition, Direct instruction, Learning disabilities, Spelling disabilities 


\section{Introduction}

Pupils with learning disabilities exhibit specific problems in the acquisition of speech and oral language, in reading, in written language, in handwriting, in spelling or in arithmetic. Moreover, there is a strong relationship among these academic skills. Pupils with spelling disabilities often have difficulties in both reading and writing and vice versa. SpearSwerling (2005) stated that spelling difficulties can hamper writing and can convey a negative impression even when the content of the writing is excellent. Also, pupils with spelling problems often fail to control, organize, and direct their thinking while engaging in spelling tasks. As a result, Lerner (2003) posited that many pupils with learning disabilities do not do well in their academic pursuits due to the difficulties they encounter with spelling. Thus, to become efficient spellers, these pupils need to learn and employ strategies that are utilized by their counterparts without spelling problems.

Buck (1988) noted that problems with spelling are common among these students and they rank as some of the most difficult problems to remediate. According to Gerber and Hall (1987) many students in the United States of America receive very little formal instruction in spelling. In Nigeria, the story is not different as spelling difficulty does not attract much consideration from many teachers, yet it is a critical area for academic success. Lerner (2003) maintained that spelling is one curriculum area in which neither creativity nor divergent thinking is encouraged. Only one pattern or arrangement of letter can be accepted as correct; no compromise is acceptable. What makes spelling so difficult is that the written form of English Language has an inconsistent pattern; there is no dependable one-toone correspondence between the spoken sounds of English and the written form of the language. Therefore, spelling is not an easy task, even for people who do not have learning disabilities.

Boder and Jarrico (1982) itemized the following as the spelling errors that some of the children with spelling disabilities often make:

(i) Dysphonetic dyslexia: This is a spelling error that reflects inaccurate phonetic spellings.

Words with spelling errors that fall in this category may have some correct letters, but the letters are placed in bizarre positions, such as "ronage" for "orange", "lghit" for "light" or "heows" for "whose". This type of error reflects a primary deficit in sound-symbol integration. Pupils with this problem read and spell primarily through visualization.

(ii) Dyseidetic: This is a spelling error that reflects phonetic-equivalent errors. Misspellings in this category include mistakes such as "lisn" for "listen”, "atenchen” for "attention”, "pese” for "peace”, "det” for "debt” and "sofer" for "chauffeur". This type of error reflects a primary deficit in the 
ability to perceive and recall whole as a gestalt. Students with this problem read and spell primarily through the process of phonic analysis.

(iii) Dysphonetic-dyseidetic dyslexia: This is a mixed type in which both kinds of errors are reflected. Pupils with these error patterns make both types of errors and they are considered the most severe cases.

Sayeski (2011) also pointed out that difficulty with spelling is a perennial challenge for students with learning disabilities. However, researchers such as Darch, Kim, Johnson and James (2000) identified instructional strategies (for instance, metacogntion, direct instruction, rulebased, multiple, resource-based, and brute force) utilized by teachers to teach students with learning disabilities to spell well. However, despite these research efforts, problems with spelling still persist among pupils with learning disabilities as evidenced by older students' poor academic performance in English Language (Nzeh, 2015). In this regard, this study focused on determining the effects of metacognition and direct instruction on spelling abilities of pupils with learning disabilities.

Metacognition as an instructional strategy, originated from Flavell's study of memory processes (Flavell, 1977). Flavell noted that although young children can learn to use developmentally lower memory strategies such as rehearsal and repetition, these children may not be able to use higher order strategies in learning unless they are prompted. This may be a strong evidence of metacognitive deficits which indicates that learners fail to monitor and to check their own learning processes.

Oxford (1990) posited that metacognitive strategies are behaviours undertaken by the learners to plan, arrange, and assess their own learning such as directed attention and self-assessment, organization, setting goals and objectives, and seeking opportunities for practice. In the same vein, Lerner (2003) identified critical metacognitive strategies required for successful learning as classification, checking, evaluation and prediction. Similarly, Nett, Goetz, Hall and Frenzel (2012) opined that the three most critical metacognitive strategies for regulating the learning process are planning, monitoring, and evaluation. These researchers affirmed through their research that out of the three metacognitive strategies, monitoring was found to positively correspond with test performance.

Several studies (such as Wong, Chang, \& Hong, 2004; Lengkanawati, 2004; Taraban, Rynearson, \& Kerr, 2004 \& Phakiti, 2003) have reported divergent findings on the use of metacognition in teaching reading to students with and without learning disabilities. For example, Phakiti (2003) reported the metacognitive reading strategies used by the EFL students and the results suggested that the students who reported using significantly higher metacognitive strategies showed better reading test performance. In another study conducted by Kraai (2012), the researcher 
focused on the role that metacognitive strategies play in second grade pupils with learning disabilities while they are performing written spelling lists and story generation tasks. One-on-one interviews were conducted with the pupils after they had written ten word spelling lists as well as a story based on a photograph of their choice. The results indicated that although their metacognitive strategies were emerging, they had difficulty reporting consistently and accurately what spelling strategies they used. They also had difficulty reflecting on whether a word was correct or incorrect and if incorrect, how to correct it. Each pupil used a different approach to spelling a word, one "Brute Force" and the other "Rule-based." Neither of these approaches worked effectively for these pupils as they made many spelling errors and still had difficulty correcting them. The overall findings indicated that these two second grade pupils with learning disabilities used limited metacognitive strategies of monitoring, regulating and reflecting.

Another strategy which could remediate spelling disabilities is Direct instruction (DI). Direct instruction conceptualised by Engelmann and Becker is a rigorously developed, highly scripted method of teaching that provides constant interaction between pupils and the teacher. It is the foremost example of instruction based on behavioural task analysis. It incorporates teacher actions that have regularly been associated with effective instruction (Brephy \& Good, 1986). According to the Texas Statewide Leadership for Autism (2011) the features of the direct instruction strategy include:

(i) using explicit, systematic instruction based on scripted lesson plans.

(ii) placing emphasis on pace and efficiency of instruction.

(iii) use of simple instructions to ensure clear communication.

(iv) conducting frequent assessments to help place students in ability groups and identify students who require additional intervention.

(v) teaching skills in sequence until students have fully internalized them and are able to generalize them.

(vi) use either group instruction or a one-to-one instructional setting.

The most beneficiary aspect of direct instruction as stated by Engelmann and Bruner (1995) is that effective teaching requires teachers to show many different examples of a concept or operation and present these examples in a way that rules out misinterpretation. Teachers must require their children to respond in ways that demonstrate they are learning. Thus, direct instruction stresses the importance of controlling the details of instruction. It ensures that children are in fact, acquiring the concepts discussed. In the opinion of (Tarver, 2001), direct instruction is a comprehensive system that integrates curriculum design with teaching techniques to produce instructional programmes in language, reading, mathematics, spelling, written expression and science. Additionally, most advocates of direct instruction such as Joyce, Weil, and Calhoun, (2003) 
agree that one of the major goals of direct instruction is the maximization of student learning time and as a result, student academic achievement.

Furthermore, the Education Consumers' Foundation (2011) metaanalyses and reviews of literature provided accumulated evidence of many different studies of direct instruction. In addition, it stressed that all of the studies confirm that the effect of direct instruction are positive and strong. For instance, a study by Flores and Ganz (2009) investigated effects of a direct instruction reading comprehension programme implemented with four students with autism and developmental delays. A functional relation between direct instruction and reading comprehension skills and behaviours was demonstrated across all behavioural conditions and across students. Data were also collected using curriculum-based assessments and all students showed improvement. In another study by Banda, Hart and Liu-Gitz (2010) two 6-year-old boys with autism spectrum disorder (ASD) were taught two social skills using direct instruction within a multiple-baseline across participants design. Both participants showed increased initiations to peers and responses to peers following the direct instruction. Thus, these studies obviously demonstrate the efficacy of direct instruction in teaching students with and without disabilities.

In addition, one moderating variable in this study is gender. Cognitive gender differences have attracted the attention of educators and psychologists. Many studies have tested the specific differences between males and females, and the first comprehensive literature review was published by Maccoby and Jacklin, (1974). The focus of their review was on three major differences between males and females: they submitted that firstly, females have better verbal skills, secondly, males have better mathematical abilities and thirdly, males have better spatial skills. Since the review of Maccoby and Jacklin (1974), many studies conducted to test cognitive abilities and gender has indicated differences on verbal performance and verbal cognitive processing (Halpern, 1992; Emanuelsson \& Svensson, 1990). Moreover, Beihler (1981) noted that female and male children in the elementary schools perform differently and concluded that girls are superior in verbal fluency, spelling and in tasks involving understanding of spatial relationship. In another study, Lazarus (2009) found no significant difference between reading achievement of male and female students exposed to two instructional strategies which are collaborative strategic reading and directed reading thinking activity.

Another variable considered as an important factor in this study is verbal ability. Verbal ability has to do with the communicative process required for the expression of our thoughts and ideas either orally or in written form (Oladunjoye, 2003). Verbal skills refer to the extent to which a person can approach words, sentences, written texts, verbs, adjectives, as 
well as, the extent to which he/she can comprehend meanings, produce synonyms and antonyms, know the meaning and use of words, complete sentences with words omitted based on the word context and have a critical view towards written speech (Testbiz, 2015). A person’s verbal ability includes such skills as comprehension, critical reasoning, grammar and vocabulary. The development of verbal ability is believed to be dependent on the learner's environment. In a study of environmental influences on teaching and learning, Brembeck (1971) found that an enriched environment stimulates verbal ability. Given that spelling problems can be enduring in pupils with learning disabilities, it becomes important that these problems are addressed at an early stage particularly before the end of primary school education. This provides support for this study.

\section{Purpose of the Study}

The aim of the present study is to examine effects of metacognition and direct instruction on spelling abilities of pupils with learning disabilities in selected primary schools in Ibadan, Oyo State, Nigeria. The researchers also examined the moderating effects of gender and verbal ability on treatment outcome.

\section{Hypotheses}

Six null hypotheses were tested at 0.05 level of significance.

1. There is no significant main effect of treatment on spelling abilities of the participants.

2. There is no significant main effect of gender on spelling abilities of participants.

3. There is no significant main effect of verbal abilities on spelling abilities of participants.

4. There is no significant interaction effect of treatment and gender on spelling abilities of participants.

5. There is no significant interaction effect of treatment and verbal abilities on spelling abilities of participants.

6. There is no significant three way interaction effect of treatment, gender and verbal abilities on spelling abilities of participants.

\section{Methodology}

The study adopted a pretest- posttest, control group, quasi experimental research design with 3x2x2 factorial matrix. The target population for the study comprised all the children with learning disabilities in primary three in Ibadan, Oyo State. Simple random sampling technique was used to select three public primary schools. To identify pupils with learning disabilities the Pupils Rating Scale developed by Myklebust (1981) 
was administered to primary three pupils in the three selected schools. One hundred and twenty pupils from the three schools were found to have learning disabilities.

The second phase of the screening was carried out to identify pupils with spelling disabilities using scores obtained from Pupils’ English note books on dictated words for the last two terms. The low performance of each child in the dictated words in English language served as an indicator that the child may likely be recommended as having spelling disabilities. Any child with average performance of fifty percent (50\%) in spelling exercises is regarded as having spelling disabilities. Only seventy-one of the one hundred and twenty pupils were identified as having spelling disabilities. In order to get the actual number of participants for this study, sixty pupils were randomly selected for the study. These sixty participants (comprising thirty boys and thirty girls) were randomly divided into three groups namely, experimental group one, experimental group two and the control group. There were twenty pupils in each of the three groups to give a total of sixty pupils in all.

Four research instruments were used in this study namely, the Pupils Rating Scale (1981) Revised with reliability coefficient of 0.76 (Lazarus, 2009), Pupils' English note books for the last two terms; Test of Verbal Ability ( $\mathrm{r}=0.96)$, and the Right Word Recognition of Jos List of one hundred (100) High Frequency words. For the current study, the researchers conducted a trial-test to further ascertain the suitability of the Right Word Recognition of Jos List of one hundred (100) High Frequency words and got a reliability coefficient of 0.91 . While the first three instruments were used for screening, and the fourth instrument was used as pre and post-test measures.

Test administration was conducted towards the end of session a period when regular classes in all public schools had been concluded; this provided the researchers the opportunity to carry out the training during normal class period. The treatment lasted for eight weeks out of which two weeks were used for pre and post-treatment assessments. For the conduct of the experiment the researchers employed the services of three trained research assistants (who are primarily, English language teachers).

Participants were exposed to treatment for six weeks, using metacognition and direct instruction strategies. During the six weeks, participants in each of the experimental groups and control received training for three hours, (3 hours) per week. The duration of each lesson was fortyfive (45) minutes. The control group was taught with conventional method.

Pupils in the metacognition instruction group were taught to:

(i) Recognise their ability to spell and the knowledge about their own memories that can effectively facilitate spelling of words. 
(ii) Use their ability to monitor the degree to which they understand information on spelling of words such as: me, we, rat, and, time, when, lion, mother, brother, father..

(iii) Recognise failure to spell correctly.

(iv) Employ repair strategies when failures are identified such as: relating different parts of words to one another, looking at the structure of the words and how such words were formed.

(v) Check for words often misspelt and identify their correct spellings.

(vi) Relate the current words to be spelt to their prior knowledge.

(vii) Evaluate pupils' own performance.

Pupils in the direct instruction group were taught to:

(i) Identify lesson objectives as stated by the researchers.

(ii) Recognize the breakdown of the lesson on spelling into simpler steps.

(iii) Listen as the researchers teach how to spell each word and ask questions.

(iv) Engage in guided practice on one- one basis as researchers directed.

(v) Engage in independent practice of how to spell using many examples given by the researchers such as: me, we, rat, and, time, when, lion, mother, brother, father.

(vi) Engage in lesson review as guided by the researchers.

The researchers moved round the three schools to supervise the trained research assistants and to offer assistance whenever it was necessary to do so. The researchers introduced varying reinforcement strategies such as clapping, praising and gift items (pens, pencils, erasers and rulers) in order to motivate the pupils during treatment period. In the eighth week after training in spelling, post test was administered using Right Word Recognition of Jos.

\section{Data Analysis}

Descriptive statistics was used to obtain means and standard deviation, while the hypotheses were tested with Analysis of Covariance (ANCOVA).

\section{Results}

$\mathrm{HO}_{1:}$ There is no significant main effect of treatment on spelling abilities of the participants. 
Table 1: Participants Spelling Abilities by Treatment, Control, Gender and Verbal Ability

\begin{tabular}{|c|c|c|c|c|c|c|}
\hline Source of Variance & $\begin{array}{c}\text { Sum of } \\
\text { square }\end{array}$ & Df & $\begin{array}{c}\text { Mean } \\
\text { square }\end{array}$ & $\mathrm{F}$ & Sig. & $\begin{array}{c}\text { Eta } \\
\text { square }\end{array}$ \\
\hline Covariance & 16410.984 & 1 & 16410.984 & 88.353 & .000 & .653 \\
\hline $\begin{array}{c}\text { Treatment Group (Main effect) } \\
\text { Gender } \\
\text { Verbal Ability }\end{array}$ & $\begin{array}{c}125.918 \\
20.765 \\
514.396\end{array}$ & $\begin{array}{l}2 \\
1 \\
1\end{array}$ & $\begin{array}{c}62.959 \\
20.765 \\
514.396\end{array}$ & $\begin{array}{l}.339 \\
.112 \\
2.769\end{array}$ & $\begin{array}{l}.714^{*} \\
.740^{*} \\
.103^{*}\end{array}$ & $\begin{array}{l}.014 \\
.002 \\
.056\end{array}$ \\
\hline $\begin{array}{l}\text { 2-way interactions } \\
\text { Treatment x Gender } \\
\text { Treatment x Verbal Ability } \\
\text { Gender x Verbal Ability }\end{array}$ & $\begin{array}{c}379.270 \\
307.102 \\
2.367 \mathrm{E}-02\end{array}$ & $\begin{array}{l}2 \\
2 \\
1\end{array}$ & $\begin{array}{c}189.635 \\
153.551 \\
2.367 \mathrm{E}-02\end{array}$ & $\begin{array}{c}1.021 \\
.827 \\
.000\end{array}$ & $\begin{array}{l}.368^{*} \\
.444^{*} \\
.991^{*}\end{array}$ & $\begin{array}{l}.042 \\
.034 \\
.000\end{array}$ \\
\hline $\begin{array}{c}\text { 3-way interactions } \\
\text { Treatment x Gender x Verbal } \\
\text { Ability }\end{array}$ & 225.388 & 2 & 112.694 & .607 & $.549 *$ & .025 \\
\hline Corrected model (Explained) & 21907.033 & 12 & 1825.586 & 9.829 & .000 & .715 \\
\hline Error (Residual) & 8729.950 & 47 & 185.744 & & & \\
\hline Corrected total & 30636.983 & 59 & & & & \\
\hline
\end{tabular}

$*$ NS $=$ Not significant at $\mathrm{P}>0.05$ level of significance

Table 1 reveals that the one-way effect of treatment groups, gender and verbal ability was not significant; the two-way interactions also indicate no significant difference based on the participants' spelling abilities. Also, there was no significant effect in the 3-way interactions on pre and post-test of participants' spelling abilities $\left(\mathrm{F}_{(2,47}=0.339, \mathrm{P}>0.05\right)$. The first hypothesis is therefore, accepted as there was no main and interaction effects among the treatment groups, gender and verbal ability respectively. Moreover, the mean scores of treatment and control are presented in Table 2.

Table 2: Mean and Standard Deviation Scores of the Treatment Groups

\begin{tabular}{|c|c|c|c|}
\hline Treatment & Mean & S.D & N \\
\hline Metacognition & 44.90 & 19.10 & 20 \\
\hline Direct instruction & 46.35 & 28.74 & 20 \\
\hline Control Group & 30.20 & 15.93 & 20 \\
\hline
\end{tabular}

Despite the fact that there was no significant main effect of the treatment, Table 2 reveals that, participants exposed to direct instruction had the highest mean score of $(\bar{x}=46.35)$. This was followed by metacognition $(\bar{x}=44.90)$ while the control group obtained $(\bar{x}=30.93)$. This indicates that direct instruction is more effective in enhancing spelling abilities of participants than metacognition and that metacognition is better than the conventional method in improving pupils' spelling abilities. 
Table 3: Mean and Standard Deviation Scores of Participants based on their Verbal Abilities

Verbal Ability

Low

High

Total

$$
\begin{gathered}
\text { Mean } \\
37.0690
\end{gathered}
$$

43.6774

40.4833
S.D

20.2430

24.8387

22.7875
$\mathrm{N}$

29

31

60

$\mathrm{HO}_{2}$ : There is no significant main effect of gender on spelling abilities of participants.

The result of the analysis as presented in Table 1 indicates that there was no significant main effect of gender on spelling abilities of participants $\left(\mathrm{F}_{(1,47}=0.112, \mathrm{P}>0.05\right)$. The null hypothesis is supported; hence the hypothesis is hereby accepted. This affirms that there was no significant main effect of gender on spelling abilities of participants.

$\mathrm{HO}_{3}$ : There is no significant main effect of verbal abilities on spelling abilities of participants.

Table 1 indicates that there was no significant main effect of verbal abilities on spelling abilities of participants $\left(\mathrm{F}_{(1,47}=2.769, \mathrm{P}>0.05\right)$. Thus, null hypothesis is accepted. It is therefore concluded that there was no significant main effect of verbal abilities on spelling abilities of participants.

$\mathrm{HO}_{4}$ : There is no significant interaction effect of treatment and gender on spelling abilities of participants

Table 1 reveals that there was no significant interaction effect of treatment and gender on spelling abilities of participants $\left(\mathrm{F}_{(2,47}=1.021, \mathrm{P}\right.$ $>0.05$ ). The null hypothesis is therefore accepted.

$\mathrm{HO}_{5}$ : There is no significant interaction effect of treatment and verbal abilities on spelling abilities of participants

The result in Table 1 reveals that there was no significant interaction effect of treatment and verbal abilities on spelling abilities of participants $\left(\mathrm{F}_{(2,47}=0.827, \mathrm{P}>0.05\right)$. Therefore, the null hypothesis is accepted. It is therefore concluded that there was no significant interaction effect of treatments and verbal abilities on spelling abilities of participants.

$\mathrm{HO}_{6}$ : There is no significant three way interaction effect of treatment, gender and verbal abilities on spelling abilities of participants

The result in Table 1 reveals that there was no significant three way interaction effect of treatments, gender and verbal abilities on spelling abilities of participants $\left(\mathrm{F}_{(2,47}=0.607, \mathrm{P}>0.05\right)$. The null hypothesis is therefore accepted. 


\section{Discussion of Findings}

The result stated that there was no significant main effect of treatment on spelling abilities of the participants. The result in table 1 indicated that there was no significant main effect of treatment on spelling abilities of the participants. This finding is in consonance with the finding of Kraai (2012) that second grade pupils with learning disabilities who had metacognitive strategies that were emerging, not only reported difficulty in consistently and accurately noting what spelling strategies they used but also had difficulty reflecting on whether a word was correct or incorrect and if incorrect, how to correct it. So, for these second grade pupils, metacognition was not effective in improving their spelling abilities.

On the other hand, this finding, contradicts the finding of Phakiti (2003) that English as Foreign Language students who used higher metacognitive reading strategies at school showed better reading test performance than those who did not use these metacognitive strategies. In other words, though spelling and reading skills are related, there is a possibility that the use of metacognition is more effective in enhancing reading ability of pupils with learning disabilities than in it is in fostering these pupils’ spelling abilities.

However, from table 2, we gather that participants in the direct instruction group had higher mean score, followed by those in the metacognition group and then, the Control Group. This shows that direct instruction is more effective in fostering spelling ability of participants than metacognition. This finding supports the postulation of the Education Consumers' Foundation (2011) that meta-analyses and reviews of literature provided accumulated evidence of many different studies of direct instruction. In addition, it stressed that all of the studies (for example, Flores \& Ganz, 2009; Banda, Hart \& Liu-Gitz, 2010) confirm that the effect of direct instruction are positive and strong in enhancing academic skills.

Furthermore, there was no significant main effect of gender on spelling abilities of participants. The ANCOVA results in Table 1 showed that there was no significant main effect of gender on spelling abilities of participants. This finding also supports the finding of Lazarus (2009), that there was no significant difference between reading achievement of male and female students exposed to two instructional strategies which are collaborative strategic reading and directed reading thinking activity.

More so, there was no significant main effect of verbal abilities on spelling abilities of participants. The result presented in Table 1 revealed that there was no significant main effect of verbal abilities on spelling abilities of participants. However, participants with high verbal abilities had the highest mean score and were followed by participants with low verbal abilities. The finding of this study negates the finding of Brembeck (1971) who carried out 
a study of environmental influences on teaching and learning, and found that an enriched environment stimulates verbal ability. Since the strategies employed in this study have empirical basis of success in other academic areas like reading, if stimulating environment is provided for pupils with learning disabilities, perhaps their verbal abilities would generally, improve. Thus, the pupils’ non-stimulating school environment could have contributed to this lack of significant main effect of verbal abilities on spelling abilities of participants as found in this study. The interaction effects of treatment and gender, treatment and verbal abilities, treatment, gender and verbal abilities were not significant on spelling abilities of participants.

\section{Conclusion}

The study revealed that pupils with spelling disabilities can acquire better spelling skills if taught with direct instruction and metacognition strategies because these two strategies have proved to be better than the conventional method. The findings of this study have confirmed the basic assumption that metacognition and direct instruction strategies would give room to pupils' active participation in the process of knowledge acquisition with reference to spelling. The findings of this study have also shed more light on the role of the teacher in a child-centered package in the school setting through the use of metacognition and direct instruction strategies.

\section{Recommendations} made:

On the basis of the findings the following recommendations are 1. Teachers in primary schools are advised to develop themselves in the use of metacognition and direct instruction, because the primary school serves as foundation for all education levels and if learners are wrongly taught at this level the resulting damage could endure for a life time.

2. Teachers must not make attempt to write-off any pupil in their classes because of his/her bad spelling abilities. Rather such a child should be taught with the strategies like metacognition and direct instruction that could aid better understanding of spelling ability.

3 Teachers should note that metacogniton and direct instruction will be more effective in small group instruction. In addition, teachers should make effort to give guided practice to pupils who require assistance; the teaching of spelling should not be restricted to spelling dictation alone.

5. Learners should be encouraged to make use of the experience garnered via the remediation strategies. 


\section{References:}

Banda, D.R., Hart, S.L., \& Liu-Gitz, L. (2010). Impact of training peers and children with autism on social skills during center time activities in inclusive classrooms. Research in Autism Spectrum Disorders, 4, 619625.

Beihler, R.F. (1981). Child Development: An Introduction on $2^{\text {nd }}$ Ed Boston: Haughton

Mufflin Company.

Boder, E. \& Jarrico, S. (1982). The Boder Test of Reading-Spelling Pattern: A Diagnostic Screening Test for Subtypes of Reading Disabilities Orlando, FI: Gruine and Stratton.Education, 36, 14-22.

Brandshaw, J. (2001). Communication partnerships with people with profound and multiple learning disabilities, Tizard Learning Disability Review, (6) 2, 6 - 15.

Brembeck, C.S. (1971). Environmental Influence in Teaching and Learning. School Foundation of Education. New York: John Wiley \& Son Inc.

Brephy, J. E. \& Good, T. L. (Ed.) (1986). Teacher behavior and student achievement. In M.C. Wittrock handbook of research on teaching third edition. New York. Macmillian.

Bruck, M. (1988). The word recognition and spelling of dyslexic children. Reading Research Quarterly, 23, 51-69.

Cooper, L. N. (1988). Learning more about learning and the brain. Proceedings of the Symposium, Disability Unbound: Challenges to the Brain and Information Technologies, RI Dept. of Mental Health, 67-70.

Darch, C; Eaves, R. C.; Crowe, D. A; Simmons, K.; Conniff, A. (2006). Teaching spelling to students with learning disabilities: A comparison of Rule-Based Strategies versus Traditional Instruction, Journal of Direct Instruction, 6 (1) 1-16. Retrieved Janaury 20, $2013 \quad$ from http://www.eric.ed.gov/ERICWebPortal/search/detailmini.jsp?

Darch, C., Kim, S., Johnson, S. \& James, H. (2000). The strategic spelling skills of students with learning disabilities: The results of two studies. Journal of Instructional Psychology, 27 (1), 15-26.

Emanuelsson, I., \& Svensson, A. (1990). Changes in intelligence over a quarter of a century. Scandinavian: Journal of Educational Research. Engelmann, S. \& Bruner, E. C. (1995). Direct Instruction- Reading. Worthington, OH: SRA Macmillan/McGraw-Hill.

Flavell, J. H. (1977). Metamemory. In R. Kail and J. Hagen ( $9^{\text {th }}$ Eds.) Perspectives on the Development of Memory and Cognition.Hillsdale, New Jersey: Lawrence Erlbaum Associates. 
Flores, M. M., \& Ganz, J. B. (2009). Effects of direct instruction on the reading comprehension of students with autism and developmental disabilities. Education and Training in Developmental Disabilities, 44 (1), 39-53.

Gerber, M. M, \& Hall, R. (1987). Cognitive-behavioral training in spelling for learning handicapped students. Learning Disability Quarterly, 159-171. Halpern, D. K. (1992). Sex differences in cognitive abilities, 2nd Edition. Hillsdale, NJ: Erlbaum.

Joyce, B., Weil, M. Calhoun, E. (2003). Models of Teaching, 7th Edition. Boston: Allyn and Bacon.

Kraai, R.V., (2012). The role of metacognitive strategy use in second grade students with learning disabilities during written spelling Tasks (Doctoral Dissertation) Ball State University, Muncie, IN. Retrieved on January 25, 2013 from http://www.michiganate.com/Publications/Issues\%20in\%20Education/Curre nt/Metacogni tion.pdf

Lerner, J. W. (2003). Learning disabilities: theories, diagnosis and teaching strategies, 9th Edition. Boston New York: Houghton Mifflin Company.

Lazarus, K. U. (2009). Two instructional strategies as intervention for enhancing reading comprehension of students with learning disabilities in Lagos State, Nigeria. Unpublished Ph.D Thesis. University of Ibadan.

Lengkanawati, N. S. (2004). How learners from different cultural backgrounds learn a foreign language [Electronic Version], 6. Retrieved January, 2006.

Maccoby, E. D. \& Jacklin, C. (1974). The psychology of sex differences. Stanford, CA: Stanford University Press.

Marchand, M. \& Martella (2002). An overview and research summary of peer-delivered corrective reading. The Behavior Analyst Today, 3 (2), $214-235$

Nett, E. N. Goetz, T. Hall, N.C. \& Frenzel, A. C. (2012). Metacognitive strategies and test performance: An experience sampling analysis of students' learning behaviour. Retrieved on January 20, 2012 from http://www.hindawi.com/journals/edu/2012/958319/

Nzeh, S. (2015). WAEC releases 2015 Nov/Dec WASSCE results. Daily Times, Retrieved on December 23, 2015, from http://dailytimes.com.ng/waec-releases-2015-novdec-wassce- results/\# Oladunjoye, S. A. (2003). The relationship between verbal ability and achievement in English language: a case study of Senior Secondary II Students. In Assuring Quality in School Practices and Strategies. An Institute of Education, Olabisi Onabanjo University, Conference Proceedings Pg 124, Ijebu-ode: Lucky Olomi Publishers. 
Oxford, R. (1990). Language learning strategies: What every teacher should know. Boston: Heinle \& Heinle.

Phakiti, A. (2003). A closer look at the relationship of cognitive and metacognitive strategy use to EFL reading achievement test performance. Language Testing, 20 (1), 26-56.

Rezvan, S., Ahmadi, S.A. \& Abedi, M.R. (2007). The effect of metacognitive training on the academic achievement and happiness of Esfahan university conditional students, Counselling Psychology Quarterly, 19 (4), 415-428,

Sayeski, K. L. (2011). Effective spelling instruction for students with learning disabilities. Retrieved on January 20, 2013 from http://isc.sagepub.com/content/47/2/75.abstract.

Taraban, R., Rynearson, K., \& Kerr, M. S. (2004). Analytic and pragmatic factors in college students' metacognitive reading strategies. Reading Psychology, 25 (2), 67-81.

Tarver, S. (2001). What the data really show: Direct instruction really works. In Wisconsin Policy Research Institute Report, UN.14, No.2.

Texas Statewide Leadership for Autism (2011). Target: Texas guide for effective teaching direct instruction. Retrieved January 21, 2013, from www.txautism.net.

Web Core IT \& Web Developments, (2007). Retrieved on June 10, 2012 from http://www.webcoreit.gr.

Wong, B.Y., Chang, S.C.A. \& Hong, (2004). Knowledge and use of metacognitive strategies.

In Learning about Learning Disabilities. Sam Drago: Academic Press.

Yang, Y. (2002). Reassessing readers' comprehension monitoring. Reading in a Foreign Language. 